\title{
The Risk Research of Traditional Retail Develop E-Business with Factor Analysis
}

\author{
Jiangping Wan, Yaqiong Liu, Yahui Zhu \\ School of Business Administration, South China University of Technology, Guangzhou, China \\ Email: csjpwan@scut.edu.cn, liu20090770212@163.com, 451517171@qq.com
}

Received 20 May 2014; revised 3 July 2014; accepted 16 July 2014

Copyright (C) 2014 by authors and Scientific Research Publishing Inc.

This work is licensed under the Creative Commons Attribution International License (CC BY). http://creativecommons.org/licenses/by/4.0/

(c) (i) Open Access

\begin{abstract}
In the context of a growing number of traditional retail to e-business transformation, the key risky factors that affect the development must be found out and its risk assessment and management approach must be studied in order to respond to the various risks in the development process. 26 risk elements affecting traditional retail develop e-business are summarized with literatures and questionnaire survey, statistical software is used to calculate the result obtained by questionnaire survey. Then 8 common factors are extracted from the 26 risk elements with factor analysis, and the influences of each factor are obtained. Finally, combining with factor score matrix, the calculation function of the risks of traditional retail develop e-business is gotten, which is used to calculate the comprehensive risk of traditional retail develop e-business.
\end{abstract}

\section{Keywords}

Traditional Retail, E-Business, Factor Analysis, Risk Assessment, Common Factors

\section{Introduction}

Today, the scale of China's online shopping population has been increasing, and e-business enterprises have great development in first-tier and second-tier cities, and gradually penetrate into third-tier or fourth-tier cities. The impact of e-business to traditional retail enterprises has been overwhelming.

Scholars at home and abroad have carried out a lot of research on retail e-business, their research are mostly analysis retail e-business current situation and existing problems. Domestic scholars are analyzed under the impact of the e-business the traditional retail enterprise how to e-business transformation, and put forward the strategies of various kinds of dealing with the problems in the transformation process.

The paper is organized as follows: Section 2 is a literature review, research methods in Section 3. Section 4 is the risk analysis of traditional retail develop e-business with factor analysis and Section 5 is the conclusion. 


\section{Literature Review}

J. W. Ross, C. M. Beath, and D. L. Goodhue put forward effective IT capability: the ability to control IT-related costs, deliver systems when needed, and effect business objectives through IT implementations. They consider the three key IT assets in the following: 1) a highly competent IT human resource, 2) a reusable technology base, and 3) a strong partnering relationship between IT and business management [1]. O. Erol, B. J. Sauser, and M. Mansouri identify two primary enablers of enterprise resilience in the following: 1) the capability of an enterprise to connect systems, people, processes and information in a way that allows enterprise to become more connected and responsive to the dynamics of its environment, stakeholders and competitors; 2) the alignment of information technology with business goals [2]. S. Wang, and N. P. Archer emphasize: 1) the difference between electronic marketplaces as governance structures and as business models, and 2) electronic marketplaces at different levels of centralization [3]. S. L. Zhang, and P. Li. study key risky factors of construction engineering design and its risk assessment and risk management with factor analysis [4]. J. P Wan, M. Zeng, and L. Y. Liang according the result of factor analysis, and set up an improved usability evaluation indicator system of electronic wallet-one card solution for college students [5]. J. P. Wan and G. H. Liu argue e-business and China enterprise competitiveness in the following: information resource, business model, knowledge management and learning organization, and suggest to update theories of management, promote team spirit, implement knowledge, establish learning network and develop strategy information services [6]. J. P Wan, and X. Y. Wan apply global IT management model to analyze the IT service management of M company, including 12 structuring elements, and the structuring elements model and their best practices are established in the IT service operation and maintenance process in the views of centers of excellence, shared services and value managers. The best practices are in the following: good relationship with customers, seamless and efficient department cooperation, team proficient in business and enterprise resource planning professional knowledge, high quality library of knowledge management and educational training [7]. J. P Wan, and J. J. Hou study the possible risk factors during SAP Business One implementation with depth interview. Results illustrate ten key risk factors, these are risk of senior managers leadership, risk of project management, risk of process improvement, risk of implementation team organization, risk of process analysis, risk of based data, risk of personnel coordination, risk of change management, risk of secondary development, and risk of data import. Focus on the key risks of SAP Business One implementation, the interpretative structural modeling approach is used to study the relationship between these factors and establish a seven-level hierarchical structure. The study illustrates that the structure is olive-like, in which the risk of data import is on the top, and the risk of senior managers is on the bottom. They are the most important risk factors [8].

\section{Research Method}

We designed the factor elements of traditional retail develop e-business from three aspects of platform business risk, management risk and information technology risk, according. Before the formal questionnaire survey, we interviewed the sector executives of traditional retail enterprise's information department, and experts in the field of e-business. The designed risk elements' completeness and accuracy can be tested through interviews, and 16 risk elements of traditional retail develop e-business after modification were gotten. At last, 26 questionnaire items were designed depending on the content of each risk element, and obey the guidance of experts (Table 1).

We divided the 26 risk factors of traditional retail develop e-business into five grades with a prevailing Likert 5 grade scale. The respondents are responsible for e-business in traditional retail enterprises. The questionnaire distributed object is one of the traditional retail enterprise, the questionnaire please information department is responsible for the company personnel orientation of e-business, without someone who's in charge of the e-business, information or other departments by the company's employee to fill in. More than 100 questionnaires were distributed in the survey, 102 questionnaires were recovered, and 99 questionnaires were valid. Moreover, 80 questionnaires were filled by the staffs in information or other departments who come from traditional retail enterprises, the ratio as high as $81 \%$. Dispersion coefficient was used to inspect the opinion coordination degree of respondents evaluated each risk factor. We did the dispersion coefficient inspection for scores of the collected risk factors collected (Table 2).

Discrete coefficients are all between $0-0.35$, that is to say the opinion coordination degree of respondents evaluated each risk factor is high, which reflects the questionnaires are reasonable and can be used for further research. Reliability inspection refers to the responsibility of data results, which were obtained with question- 
Table 1. The risk elements of traditional retail develop e-business.

\begin{tabular}{|c|c|c|}
\hline Aspects & Elements & Questionnaire items \\
\hline \multirow{8}{*}{$\begin{array}{c}\text { Platform } \\
\text { business risk }\end{array}$} & 1. product risk & $\begin{array}{l}X_{1} \text { prices of online product are more transparent } \\
X_{2} \text { higher degree homogeneity of online product }\end{array}$ \\
\hline & $\begin{array}{l}\text { 2. risk of cooperate with online } \\
\text { and offline }\end{array}$ & $\begin{array}{l}\mathrm{X}_{3} \text { conflict of online and offline business } \\
\mathrm{X}_{4} \text { conflict of online and offline channel }\end{array}$ \\
\hline & 3. logistics distribution risk & $\begin{array}{l}\mathrm{X}_{5} \text { development of logistics system development lag } \\
\mathrm{X}_{6} \text { complex distribution process } \\
\mathrm{X}_{7} \text { high cost of distribution }\end{array}$ \\
\hline & 4. marketing campaign risk & $\begin{array}{l}X_{8} \text { the poor ability of network marketing integration } \\
X_{9} \text { the high expenses of network marketing }\end{array}$ \\
\hline & 5. customer service risk & $\mathrm{X}_{10}$ customer service is not professional \\
\hline & 6. consumers risk & $\mathrm{X}_{11}$ the phenomenon of consumers compare prices are serious \\
\hline & 7. collaboration risk & $\mathrm{X}_{12}$ lack of demand for e-business partners \\
\hline & 8. competetitive risk & $\mathrm{X}_{13}$ fierce competition between online and offline peer \\
\hline \multirow{4}{*}{ Management risk } & 9. organizational structure risk & $\begin{array}{l}\mathrm{X}_{14} \text { the original functions are facing change and recombination } \\
\mathrm{X}_{15} \text { the conflict of interest between electricity and other departments }\end{array}$ \\
\hline & 10. organizational planning risk & $\begin{array}{l}\mathrm{X}_{16} \text { the lack of internal and external trends' analysis } \\
\mathrm{X}_{17} \text { the objectives of development of e-business is not clear }\end{array}$ \\
\hline & 11. executives risk & $\begin{array}{l}\mathrm{X}_{18} \text { the lack of awareness of e-business executives } \\
\mathrm{X}_{19} \text { the lack of executives' support and cooperation }\end{array}$ \\
\hline & 12. risk of corporate members & $\mathrm{X}_{20}$ the lack of outstanding e-business talents \\
\hline \multirow{4}{*}{$\begin{array}{l}\text { Information } \\
\text { technology risk }\end{array}$} & 13. information system risk & $\begin{array}{l}\mathrm{X}_{21} \text { e-business background system is not perfect } \\
\mathrm{X}_{22} \text { e-business background system docking with front shops and offline } \\
\text { systems is difficult }\end{array}$ \\
\hline & 14. website construction risk & $\begin{array}{l}X_{23} \text { website's construction ignores the brand, quality and interactive } \\
X_{24} \text { website haven't been optimized continuously }\end{array}$ \\
\hline & 15. data security risk & $\mathrm{X}_{25}$ data information has been stolen by hackers \\
\hline & 16. data analysis risk & $\mathrm{X}_{26}$ the analysis and application of data hasn't been seriously \\
\hline
\end{tabular}

naire used repeatedly. SPSS 19.0 software and the commonly Cronbach's coefficient can be used for testing. Cronbach's a coefficient is 0.866 , which is between $0.7-0.9$, indicating the high stability and reliability of the questionnaire (Table 3).

\section{The Factor Analysis for Risk Elements of Traditional Retail Develop E-Business}

If the original variables are mutually independent, and have low degree of correlation and no duplication of information, and without common factor among the variables, then there is no need for factor analysis. Therefore, it is necessary to do some analysis for determining the statistical data whether has a strong correlation between the factors and be suitable for factor analysis. We apply SPSS 19.0 to calculate questionnaire data (Table 4).

The KMO measure value is 0.697 , indicating that the correlation between the raw data is relatively strong, and factor analysis can be performed. Bartlett sphericity test value is 1535.857 , which is relatively large, and significant probability statistic is 0.000 , which is less than the specified significance level of $1 \%$, indicating that correlation coefficient matrix is not unit matrix, and relevant, equally indicating that factor analysis is appropriate. The factors with eigenvalues greater than 1 are identified as the common factors. The 26 eigenvalues of the variable correlation matrix are calculated.

The first eight factors should be extracted as common factors accordance with the principle of the extraction of eigenvalues greater than 1 . The first eight factors as common factors are selected because cumulative variance rate is $72.871 \%$, indicating that the eight common factors have been able to interpret the information of original variables well.

We should do orthogonal rotation of varimax, making each variable on eight variables common factors having relatively high loads, then get rotation component matrix In order to reflect the relationship between the va- 
Table 2. Dispersion coefficient inspection for risk factors indicators.

\begin{tabular}{|c|c|c|c|}
\hline Questionnaire indicators & Average & Standard deviation & Dispersion coefficient \\
\hline $\mathrm{X}_{1}$ prices of online product are more transparent & 4.03 & 1.775 & 0.192 \\
\hline $\mathrm{X}_{2}$ higher degree homogeneity of online product & 4.03 & 1.826 & 0.205 \\
\hline $\mathrm{X}_{3}$ conflict of online and offline business & 3.77 & 1.831 & 0.220 \\
\hline $\mathrm{X}_{4}$ conflict of online and offline channel & 3.25 & 1.003 & 0.309 \\
\hline $\mathrm{X}_{5}$ development of logistics system development lag & 3.32 & 1.946 & 0.285 \\
\hline $\mathrm{X}_{6}$ complex distribution process & 3.85 & 1.101 & 0.286 \\
\hline $\mathrm{X}_{7}$ high cost of distribution & 3.96 & 1.936 & 0.236 \\
\hline $\mathrm{X}_{8}$ the poor ability of network marketing integration & 3.66 & 1.810 & 0.221 \\
\hline $\mathrm{X}_{9}$ the high expenses of network marketing & 3.88 & 1.940 & 0.242 \\
\hline $\mathrm{X}_{10}$ customer service is not professional & 3.66 & 1.939 & 0.257 \\
\hline $\mathrm{X}_{11}$ the phenomenon of consumers compare prices are serious & 4.12 & 1.848 & 0.206 \\
\hline $\mathrm{X}_{12}$ lack of demand for e-business partners & 3.96 & 1.844 & 0.213 \\
\hline $\mathrm{X}_{13}$ fierce competition between online and offline peer & 4.05 & 1.787 & 0.194 \\
\hline $\mathrm{X}_{14}$ the original functions are facing change and recombination & 3.74 & 1.815 & 0.218 \\
\hline $\mathrm{X}_{15}$ the conflict of interest between electricity and other departments & 3.68 & 1.843 & 0.229 \\
\hline $\mathrm{X}_{16}$ the lack of internal and external trends' analysis & 3.67 & 1.769 & 0.210 \\
\hline $\mathrm{X}_{17}$ the objectives of development of e-business is not clear & 3.65 & 1.837 & 0.229 \\
\hline $\mathrm{X}_{18}$ the lack of awareness of e-business executives & 3.28 & 1.031 & 0.314 \\
\hline $\mathrm{X}_{19}$ the lack of executives' support and cooperation & 3.35 & 1.033 & 0.308 \\
\hline $\mathrm{X}_{20}$ the lack of outstanding e-business talents & 3.54 & 1.137 & 0.321 \\
\hline $\mathrm{X}_{21}$ e-business background system is not perfect & 3.88 & 1.972 & 0.251 \\
\hline $\begin{array}{l}\mathrm{X}_{22} \text { e-business background system docking with front shops and offline } \\
\text { systems is difficult }\end{array}$ & 4.02 & 1.892 & 0.222 \\
\hline $\mathrm{X}_{23}$ website's construction ignores the brand, quality and interactive & 3.66 & 1.051 & 0.287 \\
\hline $\mathrm{X}_{24}$ website haven’t been optimized continuously & 3.71 & 1.884 & 0.238 \\
\hline $\mathrm{X}_{25}$ data information has been stolen by hackers & 3.25 & 1.849 & 0.261 \\
\hline $\mathrm{X}_{26}$ the analysis and application of data hasn't been seriously & 2.91 & 1.961 & 0.330 \\
\hline
\end{tabular}

Table 3. Statistic for questionnaire reliability.

\begin{tabular}{cc} 
Cronbach's Alpha & Number of terms \\
\hline 0.866 & 26 \\
\hline
\end{tabular}

Table 4. KMO and Bartlett sphericity.

Kaiser-Meyer-Olkin measurements

Bartlett sphercity

$\begin{array}{lr}\text { df } & 325 \\ \text { sig } & 0.000\end{array}$

riable factors more clearly (Table 5). The load that various variable factors on the common factors is illustrated, it is conducive to extract the meaning of eight common factors, then the ideal common factors model for traditional retail develop e-business can be gotten. 
Table 5. Factor characteristic value, variance contribution rate and cumulative variance contribution rate.

\begin{tabular}{|c|c|c|c|c|c|c|c|c|c|}
\hline \multirow{2}{*}{ Component } & \multicolumn{3}{|c|}{ Initial characteristic value } & \multicolumn{3}{|c|}{ Load of extraction sum of squares } & \multicolumn{3}{|c|}{ Load of rotation sum of squares } \\
\hline & total & variance $\%$ & Accumulation\% & total & Variance $\%$ & Accumulation\% & total & Variance\% & Accumulation\% \\
\hline 1 & 6.744 & 25.937 & 25.937 & 6.744 & 25.937 & 25.937 & 3.059 & 11.765 & 11.765 \\
\hline 2 & 2.948 & 11.340 & 37.277 & 2.948 & 11.340 & 37.277 & 2.763 & 10.628 & 22.393 \\
\hline 3 & 1.975 & 7.597 & 44.874 & 1.975 & 7.597 & 44.874 & 2.757 & 10.602 & 32.995 \\
\hline 4 & 1.897 & 7.296 & 52.170 & 1.897 & 7.296 & 52.170 & 2.533 & 9.741 & 42.736 \\
\hline 5 & 1.729 & 6.651 & 58.821 & 1.729 & 6.651 & 58.821 & 2.503 & 9.628 & 52.363 \\
\hline 6 & 1.504 & 5.785 & 64.606 & 1.504 & 5.785 & 64.606 & 2.393 & 9.202 & 61.566 \\
\hline 7 & 1.271 & 4.890 & 69.495 & 1.271 & 4.890 & 69.495 & 1.618 & 6.221 & 67.787 \\
\hline 8 & 1.143 & 4.397 & 73.893 & 1.143 & 4.397 & 73.893 & 1.588 & 6.106 & 73.893 \\
\hline 9 & 0.907 & 3.487 & 77.380 & & & & & & \\
\hline 10 & 0.861 & 3.311 & 80.691 & & & & & & \\
\hline$\ldots \ldots$ & $\ldots \ldots$ & $\ldots \ldots$ & ...... & & & & & & \\
\hline 26 & 0.041 & 0.157 & 100.000 & & & & & & \\
\hline
\end{tabular}

The loading that 26 indicators on one common factor exceed 0.5 , and close to 0 on the remaining common factors (Table 6).

The factor variables need to be named to illustrate the main factors that have an effect on the structure of original variable system and system characteristics (Table 7).

Regression analysis is used to get factor's score matrix of 8 common factors with SPSS 19.0 (Table 8).

According to score coefficient matrix of each factor, we can calculate the score of each common factor. Calculation functions are as follows.

$$
\begin{gathered}
\mathrm{F}_{1}=-0.051 \mathrm{X}_{1}-0.064 \mathrm{X}_{2}+\cdots+0.001 \mathrm{X}_{26} \\
\mathrm{~F}_{2}=-0.023 \mathrm{X}_{1}-0.017 \mathrm{X}_{2}+\cdots-0.072 \mathrm{X}_{26} \\
\vdots \\
\mathrm{F}_{8}=-0.031 \mathrm{X}_{1}+0.154 \mathrm{X}_{2}+\cdots-0.118 \mathrm{X}_{26}
\end{gathered}
$$

Variance contribution of factors is sum of variance contribution that each principal factor provides it for all variables, and it is an index to measure the relative importance of the principal factors. The larger variance contribution is,

$$
W_{i}=\frac{c_{i}}{\sum_{i=1}^{n} c_{i}}
$$

Formula (1): $W_{i}$ means the weight of the ith principal factor to total goals; $c_{i}$ means the variance contribution of the ith principal factor; $\mathrm{n}$ means the number of principal factors.

Rates of variance contribution of 8 principal factors which are selected from Table 5: 6.774, 3.096, 2.086, $1.918,1.730,1.530,1.340,1.202$. We can get weights of all principal factors to total goals by taking these data into Formula (1) (Table 9).

According to the weight of the principal factors to the total target, comprehensive risk score of the risks of traditional retail develop e-business can be gotten:

$$
\mathrm{Z}=0.45 \mathrm{~F}_{1}+0.139 \mathrm{~F}_{2}+0.107 \mathrm{~F}_{3}+0.115 \mathrm{~F}_{4}+0.177 \mathrm{~F}_{5}+0.117 \mathrm{~F}_{6}+0.095 \mathrm{~F}_{7}+0.104 \mathrm{~F}_{8}
$$

Put the calculated $\mathrm{F}_{1}, \mathrm{~F}_{2}, \mathrm{~F}_{3}, \mathrm{~F}_{4}, \mathrm{~F}_{5}, \mathrm{~F}_{6}, \mathrm{~F}_{7}, \mathrm{~F}_{8}$ value in the Formula (2), the comprehensive risk score can be consolidated. For different traditional retail enterprises, their risk level can be calculated by the calculation. Then we can take appropriate risk management measures, depending on the circumstances of their risk level. 
Table 6. Rotation component matrix.

\begin{tabular}{|c|c|c|c|c|c|c|c|c|}
\hline \multirow{2}{*}{ No. } & \multicolumn{8}{|c|}{ Component } \\
\hline & 1 & 2 & 3 & 4 & 5 & 6 & 7 & 8 \\
\hline $\mathrm{X}_{1}$ & 0.131 & 0.132 & -0.131 & 0.373 & 0.593 & 0.336 & -0.052 & 0.042 \\
\hline $\mathrm{X}_{2}$ & 0.045 & -0.105 & -0.069 & 0.449 & 0.511 & 0.343 & -0.262 & 0.263 \\
\hline $\mathrm{X}_{3}$ & 0.195 & 0.082 & 0.076 & -0.069 & -0.118 & 0.263 & -0.001 & 0.776 \\
\hline $\mathrm{X}_{4}$ & 0.177 & 0.065 & 0.064 & 0.349 & 0.093 & -0.133 & -0.005 & 0.635 \\
\hline $\mathrm{X}_{5}$ & 0.306 & -0.146 & 0.032 & 0.600 & 0.224 & -0.160 & 0.182 & 0.269 \\
\hline $\mathrm{X}_{6}$ & 0.113 & 0.160 & 0.149 & 0.821 & 0.001 & 0.218 & 0.069 & -0.007 \\
\hline $\mathrm{X}_{7}$ & 0.088 & 0.324 & 0.174 & 0.714 & 0.100 & 0.184 & -0.016 & -0.047 \\
\hline $\mathrm{X}_{8}$ & -0.051 & 0.287 & -0.079 & -0.101 & 0.017 & 0.540 & 0.105 & 0.415 \\
\hline $\mathrm{X}_{9}$ & 0.192 & 0.129 & 0.066 & 0.141 & 0.065 & 0.858 & 0.052 & 0.035 \\
\hline $\mathrm{X}_{10}$ & 0.200 & 0.017 & -0.016 & 0.183 & 0.083 & 0.816 & -0.009 & 0.005 \\
\hline $\mathrm{X}_{11}$ & 0.158 & 0.195 & 0.217 & 0.044 & 0.792 & 0.004 & -0.057 & -0.150 \\
\hline $\mathrm{X}_{12}$ & 0.136 & 0.029 & 0.259 & -0.087 & 0.828 & 0.037 & -0.062 & -0.030 \\
\hline $\mathrm{X}_{13}$ & 0.033 & 0.232 & 0.208 & 0.368 & 0.568 & -0.106 & 0.255 & 0.213 \\
\hline $\mathrm{X}_{14}$ & 0.803 & 0.074 & 0.041 & 0.236 & 0.123 & 0.018 & -0.021 & -0.029 \\
\hline $\mathrm{X}_{15}$ & 0.779 & 0.279 & 0.032 & -0.018 & 0.117 & 0.203 & 0.125 & 0.205 \\
\hline $\mathrm{X}_{16}$ & 0.813 & 0.207 & 0.023 & -0.023 & 0.063 & 0.178 & 0.011 & 0.117 \\
\hline $\mathrm{X}_{17}$ & 0.785 & 0.217 & 0.039 & 0.226 & 0.109 & 0.094 & 0.053 & 0.133 \\
\hline $\mathrm{X}_{18}$ & 0.041 & 0.119 & 0.910 & 0.116 & 0.106 & -0.049 & 0.032 & 0.050 \\
\hline $\mathrm{X}_{19}$ & 0.016 & -0.040 & 0.929 & 0.090 & 0.106 & -0.068 & 0.053 & 0.074 \\
\hline $\mathrm{X}_{20}$ & 0.049 & 0.046 & 0.883 & 0.068 & 0.178 & 0.121 & -0.038 & -0.016 \\
\hline $\mathrm{X}_{21}$ & 0.274 & 0.744 & 0.067 & 0.067 & 0.027 & 0.281 & -0.251 & -0.127 \\
\hline $\mathrm{X}_{22}$ & 0.242 & 0.762 & 0.112 & 0.071 & 0.119 & -0.002 & 0.035 & 0.061 \\
\hline $\mathrm{X}_{23}$ & 0.184 & 0.783 & -0.060 & 0.062 & 0.176 & 0.023 & 0.056 & 0.093 \\
\hline $\mathrm{X}_{24}$ & 0.085 & 0.583 & 0.069 & 0.387 & 0.013 & 0.142 & 0.017 & 0.217 \\
\hline $\mathrm{X}_{25}$ & 0.153 & 0.228 & 0.014 & 0.131 & -0.126 & 0.231 & 0.767 & 0.162 \\
\hline $\mathrm{X}_{26}$ & -0.001 & -0.217 & 0.024 & 0.003 & 0.007 & -0.081 & 0.861 & -0.104 \\
\hline
\end{tabular}

\section{Table 7. Indicators classification.}

\begin{tabular}{ccc}
\hline No. & Risk factor variables & The name of common factors \\
\hline$F_{1}$ & $\mathrm{X}_{14}, \mathrm{X}_{15}, \mathrm{X}_{16}, \mathrm{X}_{17}$ & Risk of organizational strategic \\
$\mathrm{F}_{2}$ & $\mathrm{X}_{21}, \mathrm{X}_{22}, \mathrm{X}_{23}, \mathrm{X}_{24}$ & Risk of IT system infrastructure \\
$\mathrm{F}_{3}$ & $\mathrm{X}_{18}, \mathrm{X}_{19}, \mathrm{X}_{20}$ & Human resource risk \\
$\mathrm{F}_{4}$ & $\mathrm{X}_{5}, \mathrm{X}_{6}, \mathrm{X}_{7}$ & Risk of logistics distribution \\
$\mathrm{F}_{5}$ & $\mathrm{X}_{1}, \mathrm{X}_{2}, \mathrm{X}_{11}, \mathrm{X}_{12}, \mathrm{X}_{13}$ & Product risk \\
$\mathrm{F}_{6}$ & $\mathrm{X}_{8}, \mathrm{X}_{9}, \mathrm{X}_{10}$ & Marketing service risk \\
$\mathrm{F}_{7}$ & $\mathrm{X}_{25}, \mathrm{X}_{26}$ & Risk of data operation \\
$\mathrm{F}_{8}$ & $\mathrm{X}_{3}, \mathrm{X}_{4}$ & Risk of cooperate with online and offline
\end{tabular}


Table 8. Factor score coefficient matrix.

\begin{tabular}{|c|c|c|c|c|c|c|c|c|}
\hline No. & 1 & 2 & 3 & 4 & 5 & 6 & 7 & 8 \\
\hline $\mathrm{X}_{1}$ & -0.051 & -0.023 & -0.125 & 0.084 & 0.250 & 0.103 & -0.002 & -0.031 \\
\hline $\mathrm{X}_{2}$ & -0.064 & -0.147 & -0.082 & 0.143 & 0.191 & 0.111 & -0.168 & 0.154 \\
\hline $\mathrm{X}_{3}$ & -0.005 & -0.033 & 0.049 & -0.144 & -0.058 & 0.061 & -0.057 & 0.546 \\
\hline $\mathrm{X}_{4}$ & -0.007 & -0.026 & -0.015 & 0.104 & -0.002 & -0.168 & -0.069 & 0.436 \\
\hline $\mathrm{X}_{5}$ & 0.094 & -0.151 & -0.051 & 0.262 & 0.031 & -0.157 & -0.056 & 0.120 \\
\hline $\mathrm{X}_{6}$ & -0.032 & -0.011 & 0.023 & 0.415 & -0.152 & 0.040 & -0.006 & -0.136 \\
\hline $\mathrm{X}_{7}$ & -0.061 & 0.081 & 0.024 & 0.343 & -0.096 & 0.015 & -0.039 & -0.146 \\
\hline $\mathrm{X}_{8}$ & -0.153 & 0.099 & -0.023 & -0.161 & 0.041 & 0.229 & 0.079 & 0.272 \\
\hline $\mathrm{X}_{9}$ & -0.007 & -0.062 & 0.045 & -0.022 & -0.027 & 0.414 & 0.041 & -0.087 \\
\hline $\mathrm{X}_{10}$ & 0.021 & -0.117 & 0.012 & 0.020 & -0.018 & 0.397 & -0.001 & -0.104 \\
\hline $\mathrm{X}_{11}$ & -0.003 & 0.047 & -0.003 & -0.106 & 0.364 & -0.029 & 0.024 & -0.113 \\
\hline $\mathrm{X}_{12}$ & 0.001 & -0.035 & 0.023 & -0.190 & 0.408 & 0.007 & 0.020 & -0.062 \\
\hline $\mathrm{X}_{13}$ & -0.116 & 0.081 & -0.081 & 0.062 & 0.246 & -0.123 & 0.173 & 0.122 \\
\hline $\mathrm{X}_{14}$ & 0.358 & -0.109 & -0.008 & 0.068 & -0.046 & -0.071 & -0.060 & -0.131 \\
\hline $\mathrm{X}_{15}$ & 0.282 & -0.006 & -0.005 & -0.132 & 0.003 & 0.010 & 0.049 & 0.046 \\
\hline $\mathrm{X}_{16}$ & 0.332 & -0.045 & 0.004 & -0.105 & -0.037 & 0.007 & -0.029 & -0.014 \\
\hline $\mathrm{X}_{17}$ & 0.302 & -0.042 & -0.012 & 0.029 & -0.044 & -0.055 & -0.015 & -0.021 \\
\hline $\mathrm{X}_{18}$ & -0.016 & 0.017 & 0.349 & -0.008 & -0.062 & -0.014 & -0.011 & 0.014 \\
\hline $\mathrm{X}_{19}$ & -0.004 & -0.056 & 0.362 & -0.016 & -0.052 & -0.006 & -0.001 & 0.042 \\
\hline $\mathrm{X}_{20}$ & -0.005 & -0.036 & 0.345 & -0.042 & -0.024 & 0.086 & -0.041 & -0.037 \\
\hline $\mathrm{X}_{21}$ & 0.018 & 0.294 & 0.018 & -0.020 & -0.075 & 0.056 & -0.145 & -0.163 \\
\hline $\mathrm{X}_{22}$ & -0.024 & 0.335 & 0.002 & -0.051 & 0.006 & -0.101 & 0.031 & -0.008 \\
\hline $\mathrm{X}_{23}$ & -0.066 & 0.357 & -0.076 & -0.061 & 0.064 & -0.096 & 0.058 & 0.023 \\
\hline $\mathrm{X}_{24}$ & -0.105 & 0.235 & -0.008 & 0.135 & -0.074 & -0.033 & -0.010 & 0.083 \\
\hline $\mathrm{X}_{25}$ & -0.034 & 0.083 & -0.011 & -0.013 & -0.044 & 0.087 & 0.476 & 0.015 \\
\hline $\mathrm{X}_{26}$ & 0.001 & -0.072 & -0.015 & -0.023 & 0.074 & 0.010 & 0.558 & -0.118 \\
\hline
\end{tabular}

Table 9. Weight of the principal factors to the total target.

\begin{tabular}{cccccccccc}
\hline Principal factor & $\mathrm{F}_{1}$ & $\mathrm{~F}_{2}$ & $\mathrm{~F}_{3}$ & $\mathrm{~F}_{4}$ & $\mathrm{~F}_{5}$ & $\mathrm{~F}_{6}$ & $\mathrm{~F}_{7}$ & $\mathrm{~F}_{8}$ \\
\hline Weight & 0.145 & 0.139 & 0.107 & 0.115 & 0.177 & 0.117 & 0.095 & 0.104 \\
\hline
\end{tabular}

\section{Conclusion}

We identified 26 risk factors of traditional retail develop e-business. 8 common factors were extracted from the 26 risk elements and their corresponding weights were obtained with factor analysis. We can calculate the comprehensive risk score with risk calculation functions to provide decision-making basis for evaluate and management the risks of traditional retail develop e-business. However, how to take control measures effectively is needed to be further studied for the influence of different factors.

\section{References}

[1] Ross, J.W., Beath, C.M. and Goodhue, D.L. (1996) Develop Long-Term Competitiveness through IT Assets. Sloan 
Management Review, Fall.

[2] Wang, S. and Archer, N.P. (2007) Electronic Marketplace Definition and Classification: Literature Review and Clarifications. Enterprise Information Systems, 1, 89-112. http://dx.doi.org/10.1080/17517570601088380

[3] Erol, O., Sauser, B.J. and Mansouri, M. (2010) A Framework for Investigation into Extended Enterprise Resilience. Enterprise Information Systems, 4, 111-136. http://dx.doi.org/10.1080/17517570903474304

[4] Zhang, S.L. and Li, P. (2011) Empirical Research of Construction Engineering Design Risk Factors Based on Factor Analysis. China Safety Science Journal, 21, 131-138.

[5] Wan, J.P., Zeng, M. and Liang, L.Y. (2013) Empirical Study on Usability Impact Factors of Electronic Wallet-One Card Solution within College Students. iBusiness, 5, 77-85.

[6] Wan, J.P. and Liu, G.H. (2000) On E-Business and China Enterprise Competitiveness. Journal of Guangdong AIB Management College, 16, 34-38.

[7] Wan, J.P. and Wan, X.Y. (2012) Case Study on M Company Best Practice with Global IT Management. Technology and Investment, 3, 143-148. http://dx.doi.org/10.4236/ti.2012.33019

[8] Wan, J.P. and Hou, J.J. (2012) Research on SAP Business One Implementation Risk Factors with Interpretive Structural Model. Journal of Software Engineering and Applications, 5, 147-155. http://dx.doi.org/10.4236/jsea.2012.53022 
Scientific Research Publishing (SCIRP) is one of the largest Open Access journal publishers. It is currently publishing more than 200 open access, online, peer-reviewed journals covering a wide range of academic disciplines. SCIRP serves the worldwide academic communities and contributes to the progress and application of science with its publication.

Other selected journals from SCIRP are listed as below. Submit your manuscript to us via either submit@scirp.org or Online Submission Portal.
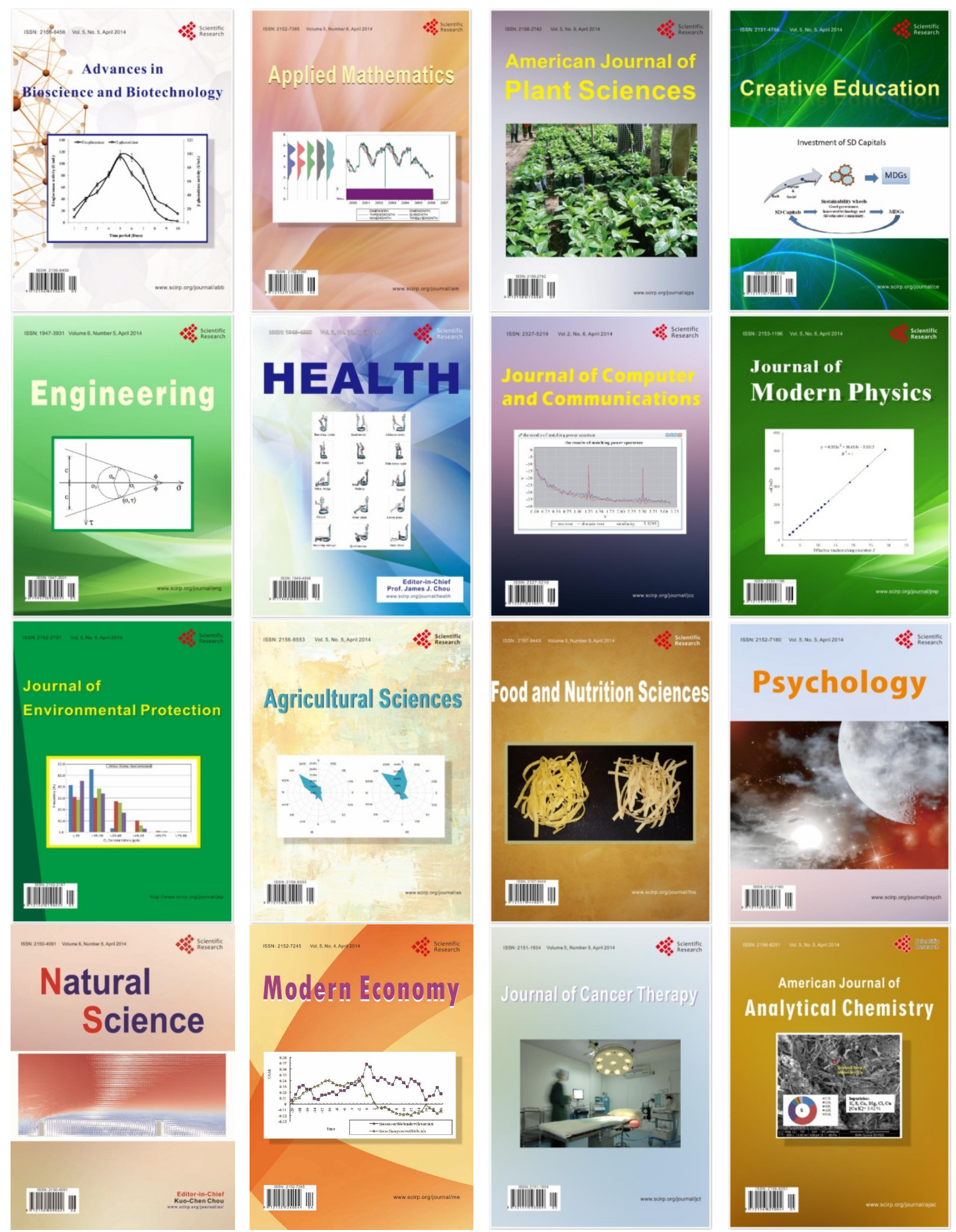